\title{
Deinococcus xinjiangensis sp. nov., isolated from desert soil
}

\author{
Fang Peng, Lei Zhang, Xuesong Luo, Jun Dai, Hongli An, Yali Tang \\ and Chengxiang Fang
}

Correspondence

Chengxiang Fang

cxfang@whu.edu.cn
College of Life Sciences, Wuhan University, Wuhan 430072, PR China

\begin{abstract}
A Gram-positive-staining, spherical-shaped and faintly pink-pigmented bacterial strain, $\mathrm{X}-82^{\top}$, was isolated from soil samples collected from a desert in Xinjiang, China. The organism was found to be resistant to UV radiation but sensitive to gamma radiation and desiccation. The optimum growth $\mathrm{pH}, \mathrm{NaCl}$ concentration and temperature were $\mathrm{pH} 7.0,0-1 \% \mathrm{NaCl}$ and $30{ }^{\circ} \mathrm{C}$. Phylogenetic analysis based on the 16S rRNA gene sequence indicated that strain $\mathrm{X}-82^{\top}$ is member of a novel species belonging to the genus Deinococcus, with Deinococcus hopiensis $\mathrm{KR}-140^{\top}$ as its closest relative (93.5\% similarity). The DNA G+C content (60 mol\%), quinone type (MK-8), major cellular fatty acids $(16: 1 \omega 7 c, 16: 0$ and $17: 1$ iso $\omega 9 c)$, the presence of peptidoglycan with L-ornithine and the dominant polar lipid (phosphoglycolipids and glycolipids) support the affiliation of strain $\mathrm{X}-82^{\top}$ with the genus Deinococcus. A novel species is proposed, for which the name Deinococcus xinjiangensis sp. nov. is proposed, with the type strain $\mathrm{X}-82^{\top}$ $\left(={\text { CCTCC AB } 207226^{\top}=\text { NRRL B-51287 }}^{\top}\right)$.
\end{abstract}

The genus Deinococcus, which represents a deep-branching lineage within the Bacteria, comprises 26 species with validly published names at the time of writing, isolated from various environments such as desert soils, foods, faeces, dust, hot springs, Antarctic environments and the plant rhizosphere (Rainey et al., 2005; Ferreira et al., 1997; Lai et al., 2006; Weon et al., 2007; Anderson et al., 1956; Davis et al., 1963; Lewis, 1973; Masters et al., 1991; Oyaizu et al., 1987; Hirsch et al., 2004). The most striking characteristic of species of the genus is their extreme resistance to UV light, gamma radiation and desiccation. Deinococcus radiodurans, the type species of the genus, has been shown to survive exposure to doses of gamma radiation greater than $20 \mathrm{kGy}$ (Daly et al., 2004; Ito et al., 1983; Anderson et al., 1956). However, around the time of writing, four psychrophilic, ionizing-radiation-sensitive Deinococcus species were described (Callegan et al., 2008). It has been suggested that resistance to unnaturally large doses of ionizing radiation is a consequence of the ability to repair desiccation-induced double-strand breaks in the DNA, similar to those produced by ionizing radiation, while UV resistance is conferred by two nucleotide excision-repair pathways acting simultaneously

The GenBank/EMBL/DDBJ accession number for the $16 \mathrm{~S}$ rRNA gene sequence of strain $X-82^{\top}$ is EU626561.

Fatty-acid profiles of strain $\mathrm{X}-82^{\top}$ and related type strains, polar-lipid profiles following 2D TLC separation, representative survival curves in response to UV and gamma radiation and 16S rRNA gene sequencebased UPGMA, maximum-parsimony and minimum-evolution trees are available as supplementary material with the online version of this paper.
(Mattimore \& Battista, 1996; Minton, 1994). Recently, a UV-radiation-resistant but gamma-radiation- and desiccation-sensitive bacterium, strain $\mathrm{X}-82^{\mathrm{T}}$, was isolated from non-irradiated soil samples collected from a desert in Xinjiang, China. The faintly pink-pigmented bacterium was identified as a novel member of the genus Deinococcus.

In the course of a study on the diversity of culturable bacteria in the Taklimakan desert of Xinjiang, China, a soil sample collected from the desert was suspended in $1.0 \mathrm{ml}$ sterile water and homogenized for $5 \mathrm{~min}$ in a sterile mortar. The resulting supernatant was serially diluted and spread on tenfold-diluted trypticase soy broth (TSB/10; $3 \mathrm{~g}$ $1^{-1}$ ) agar plates (Bacto; Becton Dickinson). Plates were incubated at $28{ }^{\circ} \mathrm{C}$ for 7 days and colonies with different morphologies were subcultured to obtain pure cultures. Among the organisms isolated in this study (about 600 pure cultures), we selected randomly 80 pure cultures for $16 \mathrm{~S}$ rRNA gene sequencing and further chemotaxonomic and phenotypic study. Strain $\mathrm{X}-82^{\mathrm{T}}$ was isolated during the sampling campaign and was observed in the lag, exponential and stationary phases of growth under phase-contrast microscopy (Olympus). To test the Gram reaction, a Gram-stain kit and the KOH lysis test (Buck, 1982) were used. Conventional biochemical tests were performed as described by Smibert \& Krieg (1994) such as gelatinase, catalase and cytochrome oxidase activities, $\mathrm{H}_{2} \mathrm{~S}$ production and casein hydrolysis. Biolog GP2 plates and API $20 \mathrm{NE}$ strips, API ID $32 \mathrm{GN}$ and API ZYM (bioMérieux) were used for classical and phenotypic tests according to the manufacturers' instructions. The temperature range 
$\left(4-50{ }^{\circ} \mathrm{C}\right)$ and $\mathrm{pH}$ range $(\mathrm{pH} 4-10)$ for growth and the requirement for $\mathrm{NaCl}(0.2-5 \%)$ were determined using $\mathrm{TSB} / 10$.

Genomic DNA extraction, PCR-mediated amplification of the $16 \mathrm{~S}$ rRNA gene and sequencing of PCR products were carried out as described by Lin et al. (2004). Pairwise alignment with sequences of a broad selection of related species and calculations of levels of sequence similarity were carried out using the BLAST facility at the EzTaxon website (http://www.eztaxon.org/search; Chun et al., 2007). Phylogenetic analyses were performed using the MEGA 3 program (Kumar et al., 2004). Phylogenetic dendrograms were constructed using the neighbour-joining, UPGMA, minimum-evolution and maximum-parsimony methods with bootstrap values based on 1000 replications.

Respiratory quinones were extracted and separated by HPLC (Ultimate 3000) as described by Xie \& Yokota (2003). Fatty acid methyl esters were extracted and analysed by GC (Hewlett Packard 6890N) according to the standard protocol of the Microbial Identification System (MIDI) using cells grown on TSB/10 agar plates for $48 \mathrm{~h}$ at $30{ }^{\circ} \mathrm{C}$. The peptidoglycan was prepared and analysed as described by Schleifer \& Kandler (1972). The DNA $\mathrm{G}+\mathrm{C}$ content was determined by HPLC according to the method of Mesbah et al. (1989). Polar lipids were extracted and analysed by two-dimensional TLC according to Tindall (1990).

To determine the tolerance of the culture to UV radiation, strains were grown in the appropriate liquid medium to the exponential phase. The cells were recovered by centrifugation, washed and resuspended in $0.067 \mathrm{M}$ potassium phosphate buffer at $\mathrm{pH}$ 7.0. Aliquots were spread on TGY ( $0.5 \%$ tryptone, $0.3 \%$ yeast extract, $0.1 \%$ glucose, $\mathrm{pH} 7.0$ ) agar plates; the plates, with their lids open, were exposed immediately to UV (UV-C, $254 \mathrm{~nm}$ ) for the desired dose, monitored by using a Spectroline DRC-100H digital radiometer (Bioblock Scientific), and incubated at $30{ }^{\circ} \mathrm{C}$ for 1 week. Aliquots of cells prepared as described above were exposed to gamma radiation from a cobalt-60 source at a dose of $600 \mathrm{~Gy} \mathrm{~h}^{-1}$ for gamma-radiation-resistance determination, while further aliquots were dried over $\mathrm{CaSO}_{4}$ and kept at $5 \%$ relative humidity until rehydration in order to determine the desiccation resistance of the culture. After exposure to gamma radiation or desiccation and rehydration, suspensions were dilution-plated in triplicate on TGY agar plates. At the same time, $D$. radiodurans DSM $20539^{\mathrm{T}}$ and Escherichia coli DH5 $\alpha$ (=ATCC 35607) were tested as positive and negative controls. Relative survival was determined by comparing with unirradiated cultures.

Strain $\mathrm{X}-82^{\mathrm{T}}$ stained Gram-positive and the cells were aerobic, non-motile and spherical $(2.0-3.0 \mu \mathrm{m}$ in diameter). The colonies were opaque, circular with entire edges and faintly pink-pigmented on TGY agar plates. The temperature range for growth was $10-37^{\circ} \mathrm{C}$, with optimum growth at $30{ }^{\circ} \mathrm{C}$. The $\mathrm{pH}$ range for growth was
$\mathrm{pH}$ 5.0-8.0, with optimum growth at $\mathrm{pH}$ 7.0. The strain was able to grow in the presence of $1 \%(\mathrm{w} / \mathrm{v}) \mathrm{NaCl}$. The strain was positive for cytochrome oxidase and catalase activities, $\mathrm{H}_{2} \mathrm{~S}$ production and hydrolysis of casein and gelatin. Other physiological and biochemical properties of strain $\mathrm{X}-82^{\mathrm{T}}$ are listed in Table 1 or in the species description.

A 16S rRNA gene sequence of $1381 \mathrm{nt}$ was determined for strain $\mathrm{X}-82^{\mathrm{T}}$. Comparative sequence and phylogenetic analysis grouped the strain within the radiation of species that currently comprise the genus Deinococcus (Fig. 1 and Supplementary Fig. S1, available in IJSEM Online). The levels of $16 \mathrm{~S}$ rRNA gene sequence similarity between strain $\mathrm{X}-82^{\mathrm{T}}$ and other Deinococcus species were in the range 89$93 \%$, the highest sequence similarities being found with Deinococcus hopiensis KR-140 ${ }^{\mathrm{T}}$ (93.5\%), D. ficus CC-FR2$10^{\mathrm{T}}(93.2 \%)$, D. mumbaiensis CON $-1^{\mathrm{T}}(93.1 \%)$, D. indicus $\mathrm{Wt} / 1 \mathrm{a}^{\mathrm{T}}(92.6 \%)$ and $D$. radiodurans DSM $20539^{\mathrm{T}}$ $(92.4 \%)$. These values are significantly below the level generally regarded to demarcate species $(97 \%)$. The DNA $\mathrm{G}+\mathrm{C}$ content was $60 \mathrm{~mol} \%$, a value that is within the range found for other species of the genus Deinococcus (59.4-70.0 mol\%; Hirsch et al., 2004).

The major fatty acids of strain $\mathrm{X}-82^{\mathrm{T}}$ were monounsaturated and straight-chain saturated fatty acids, such as $\mathrm{C}_{16: 1} \omega 7 c(22.59 \%)$ and $\mathrm{C}_{16: 0}(11.05 \%)$, which were also predominant in most other Deinococcus species. Specifically, larger amounts of iso-branched fatty acids were also found, such as $\mathrm{C}_{17: 1}$ iso $\omega 9 c(24.06 \%)$ and $\mathrm{C}_{17: 0}$ iso $(6.21 \%)$, which were also found in Deinococcus murrayi and Deinococcus radiopugnans (Ferreira et al., 1997) (Supplementary Table S1). The peptidoglycan of strain $\mathrm{X}-82^{\mathrm{T}}$ contained ornithine, glutamic acid, alanine and glycine at a molar ratio of $1: 1: 2: 2\left(\mathrm{Orn}-\mathrm{Gly}_{2}\right.$; type $\left.\mathrm{A} 3 \beta\right)$, as reported for D. radiodurans DSM $20539^{\mathrm{T}}$. The major respiratory quinone was menaquinone $8(\mathrm{MK}-8)$, as in all recognized Deinococcus strains. Strain $\mathrm{X}-82^{\mathrm{T}}$ had a complex polar lipid profile consisting of different unidentified glycolipids, phospholipids and phosphoglycolipids (Supplementary Fig. S2) but which did not include phosphatidylglycerol, consistent with previously reported results for other Deinococcus species (Embley et al., 1987; Counsell \& Murray, 1986; Thompson et al., 1980). A predominant phosphoglycolipid (PGL2), which was identified in $D$. radiodurans as $2^{\prime}-O-(1,2$-diacyl-sn-glycero-3phospho)-3'-O-( $\alpha$-galactosyl $)-N$-D-glyceroyl alkylamine (Anderson \& Hansen, 1985), was also detected. The chromatographic behaviour of the polar lipids aminophospholipid (APL) and PGL1 of strain X-82 ${ }^{\mathrm{T}}$ was similar to polar lipid spots reported for D. radiodurans, D. ficus (Lai et al., 2006), D. deserti (Weon et al., 2007), D. geothermalis (Ferreira et al., 1997) and D. aquiradiocola (Asker et al., 2009). However, the significantly larger amounts of GL1GL3 clearly distinguished $\mathrm{X}-82^{\mathrm{T}}$ from other members of the genus Deinococcus. In addition, it differed from Deinococcus altitudinis, D. alpinitundrae, D. radiomollis and $D$. claudionis, the four ionizing radiation-sensitive 
Table 1. Phenotypic differences between strain $\mathrm{X}-82^{\top}$ and related members of the genus Deinococcus

Strains: 1 , strain X-82 ${ }^{\mathrm{T}}$; 2, D. radiodurans DSM $20539^{\mathrm{T}}$ (data from this study); 3, D. ficus CC-FR2-10 ${ }^{\mathrm{T}}$ (data from Lai et al., 2006); 4, D. indicus Wt/1a ${ }^{\mathrm{T}}$ (Suresh et al., 2004; Weon et al., 2007); 5, D. hopiensis KR-140 (Rainey et al., 2005; this study). + , Positive result or growth; -, negative result or growth; ND, no data available.

\begin{tabular}{|c|c|c|c|c|c|}
\hline Characteristic & 1 & 2 & 3 & 4 & 5 \\
\hline Morphology & Spherical & Spherical & Rod & Rod & Spherical \\
\hline Pigmentation & Faint pink & Red & Pale pink & Red & Pink \\
\hline \multicolumn{6}{|l|}{ Utilization of: } \\
\hline L-Arabinose & - & - & + & + & + \\
\hline Lactose & - & - & + & + & - \\
\hline Trehalose & + & + & + & $\mathrm{ND}$ & + \\
\hline D-Xylose & - & - & + & $\mathrm{ND}$ & + \\
\hline Melibiose & - & - & + & + & - \\
\hline $\mathrm{N}$-Acetyl-D-glucosamine & - & + & + & + & + \\
\hline L-Alanine & + & - & - & - & - \\
\hline D-Mannitol & + & - & + & - & - \\
\hline D-Galactose & + & - & + & - & + \\
\hline L-Rhamnose & - & - & + & + & + \\
\hline Raffinose & - & - & + & + & - \\
\hline \multicolumn{6}{|l|}{ API ZYM test results } \\
\hline Valine arylamidase & + & - & - & - & - \\
\hline$\beta$-Galactosidase & - & - & + & + & - \\
\hline$\beta$-Glucosidase & - & - & + & - & + \\
\hline Gelatinase & + & + & + & + & + \\
\hline Casein hydrolysis & - & + & $\mathrm{ND}$ & + & + \\
\hline Nitrate reduction & - & + & ND & + & - \\
\hline
\end{tabular}

species reported recently by Callegan et al. (2008), and $D$. cellulosilyticus by the presence of PGL1 and by the absence of APGL for D. altitudinis and D. alpinitundrae. The lack of APL in Deinococcus aquatilis (Kämpfer et al., 2008), D. indicus (Ferreira et al., 1997), D. marmoris (Callegan et al., 2008), D. aquaticus and D. caeni (Im et al., 2008) distinguished them from the isolate.

There was no growth for E. coli DH5 $\alpha$ at a dose of $3.0 \mathrm{kGy}$ gamma radiation, after 6 weeks of desiccation or after exposure to a UV dose of $30 \mathrm{~J} \mathrm{~m}^{-2}$. Strain $\mathrm{X}-82^{\mathrm{T}}$ appeared to be somewhat resistant to these stresses, but less so than D. radiodurans DSM $20539^{\mathrm{T}}$ (Supplementary Fig. S3). Exposure of cultures to $5 \mathrm{kGy}$ gamma radiation resulted in survival of $1-0.5 \%$ for X-82 ${ }^{\mathrm{T}}$, compared with $90-85 \%$ for D. radiodurans DSM $20539^{\mathrm{T}}$. At the higher dose tested (10 $\mathrm{kGy}$, $\mathrm{X}-82^{\mathrm{T}}$ did not survive, whereas most Deinococcus species have been shown to survive. Increased sensitivity to DNA damage was also observed when the desiccation resistance of these strains was compared. The viability of the $\mathrm{X}-82^{\mathrm{T}}$ culture decreased to $6-7 \%$ after 6 weeks of desiccation, which is approximately 10 -fold more sensitive than $D$. radiodurans DSM $20539^{\mathrm{T}}$. As for UV radiation tolerance, 1.7 and $12 \%$ survival was observed for $\mathrm{X}-82^{\mathrm{T}}$ and $D$. radiodurans DSM $20539^{\mathrm{T}}$, respectively, when they were exposed to a UV dose of $810 \mathrm{~J} \mathrm{~m}^{-2}$.

Although strain $\mathrm{X}-82^{\mathrm{T}}$ was somewhat more sensitive to gamma radiation and desiccation than other species of the genus Deinococcus, the UV-radiation resistance and the combination of chemotaxonomic and phenotypic characteristics corroborate the results of the 16S rRNA gene sequence analysis, indicating that strain $\mathrm{X}-82^{\mathrm{T}}$ represents a novel species of the genus Deinococcus, for which the name Deinococcus xinjiangensis sp. nov. is proposed.

\section{Description of Deinococcus xinjiangensis sp. nov.}

Deinococcus xinjiangensis (xin.jiang.en'sis. N.L. masc. adj. xinjiangensis pertaining to Xinjiang, an autonomous region in north-western China, where the type strain was isolated).

Cells stain Gram-positive and are non-motile, aerobic and spherical. Colonies on TGY agar medium are opaque, circular with entire edges, faintly pink-pigmented and 3$4 \mathrm{~mm}$ in diameter. The optimum growth $\mathrm{pH}, \mathrm{NaCl}$ concentration and temperature are $\mathrm{pH} 7.0,0-1 \%$ and $30{ }^{\circ} \mathrm{C}$. Sensitive to gamma radiation $(<10 \mathrm{kGy})$ and desiccation but resistant to UV irradiation $\left(>810 \mathrm{~J} \mathrm{~m}^{-2}\right)$. The major cellular fatty acids are $16: 1 \omega 7 c, 16: 0$ and $17: 1$ iso $\omega 9 c$. The peptidoglycan contains L-ornithine (Orn$\mathrm{Gly}_{2}$; type $\left.\mathrm{A} 3 \beta\right)$. MK-8 is the predominant lipoquinone. The polar lipid profile contains two unknown phosphoglycolipids, three glycolipids, one unknown aminophospholipid and one unknown phospholipid. One of the phosphoglycolipids and the three glycolipids are the major polar lipids. DNA of the type strain has a $\mathrm{G}+\mathrm{C}$ content of $60 \mathrm{~mol} \%$. Positive for activities of urease, gelatinase, catalase, cytochrome oxidase, alkaline phosphatase, butyrate esterase, caprylate esterase, leucine arylamidase, 


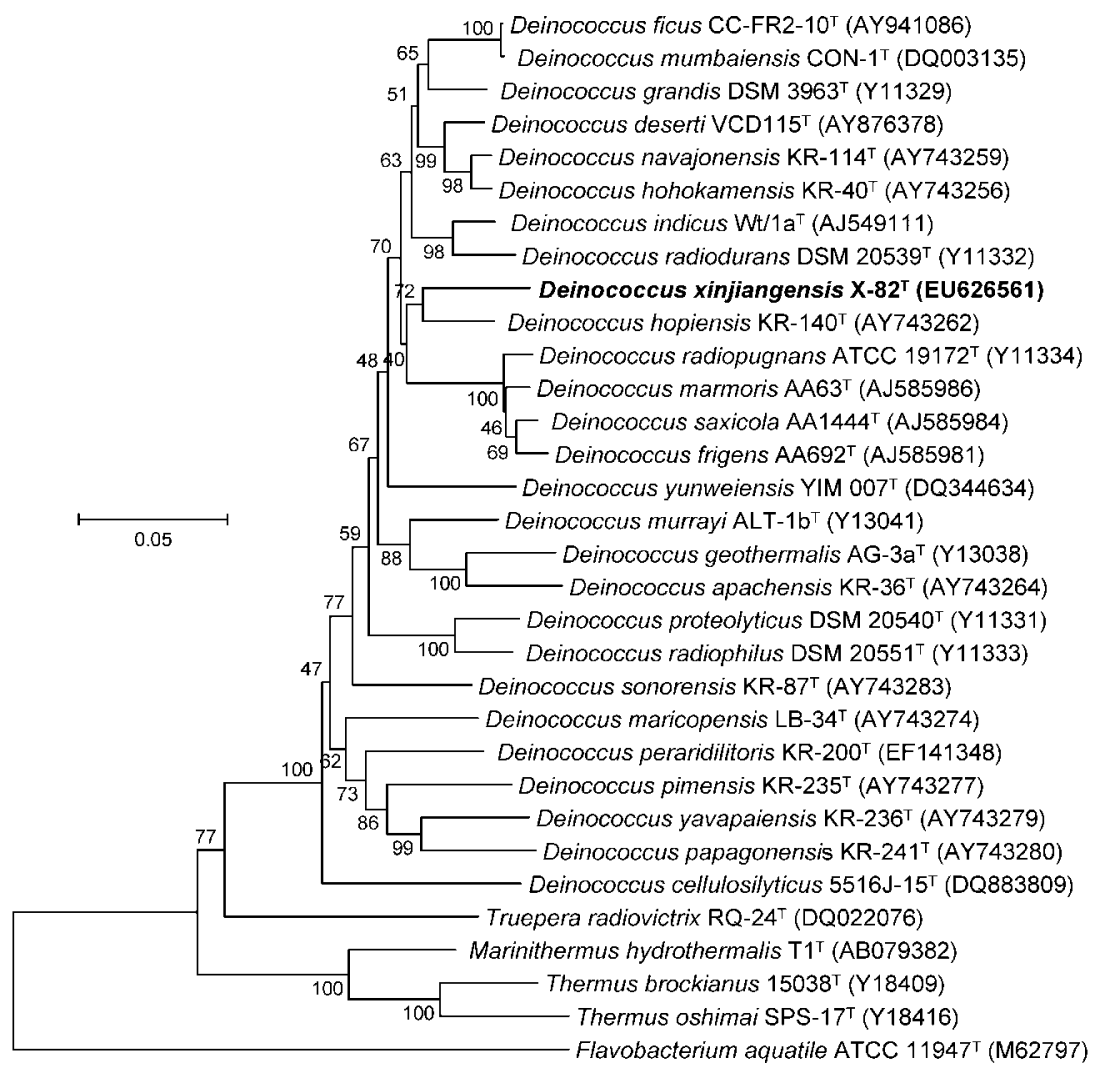

Fig. 1. Phylogenetic dendrogram showing the phylogenetic position of strain $\mathrm{X}-82^{\top}$ based on $16 S$ rRNA gene sequences available from the EMBL database (accession numbers in parentheses), constructed from distance matrices (according to the Kimura-2 model) and clustered with the neighbour-joining method by using the software package MEGA, version 3.1 (Kumar et al., 2004). Bootstrap values, expressed as percentages of 1000 replications, are given at branching points. Flavobacterium aquatile ATCC $11947^{\top}$ (Weeks, 1955) was used as the outgroup. Bar, $0.05 K_{\text {nuc }}$ value. UPGMA, maximumparsimony and minimum-evolution trees are available as Supplementary Fig. S1. valine arylamidase, acid phosphatase, naphthol-AS-BIphosphohydrolase and $\alpha$-glucosidase. The following compounds are utilized as sole carbon sources (i.e. produce positive results in the Biolog system): dextrin, glycogen, Tween 40, Tween 80, D-fructose, D-galactose, $\alpha$-D-glucose, maltose, maltotriose, D-mannitol, palatinose, D-psicose, sucrose, trehalose, turanose, $\alpha$-ketovaleric acid, pyruvic acid methyl ester, succinic acid monomethyl ester, Lalanine, L-asparagine, glycerol, adenosine, $2^{\prime}$-deoxyadenosine, thymidine, adenosine $5^{\prime}$-monophosphate, thymidine $5^{\prime}$-monophosphate, D-fructose 6-phosphate, $\alpha$-D-glucose 1-phosphate, D-glucose 6-phosphate and DL- $\alpha$-glycerol phosphate. The type strain assimilates sucrose, maltose, glycogen, mannitol and glucose.

The type strain, X-82 ${ }^{\mathrm{T}}$ (=CCTCC AB $207226^{\mathrm{T}}=$ NRRL B$51287^{\mathrm{T}}$ ), was isolated from soil of the Taklimakan desert, Xinjiang, China.

\section{Acknowledgements}

This research was supported by the R \& D Infrastructure and Facility Development Program from the Ministry of Science and Technology of the People's Republic of China (grant no. 2005DKA21208).

\section{References}

Anderson, R. \& Hansen, K. (1985). Structure of a novel phosphoglycolipid from Deinococcus radiodurans. J Biol Chem 260, 12219-12223.
Anderson, A. W., Nordan, H. C., Cain, R. F., Parrish, G. \& Duggan, D. (1956). Studies on a radio-resistant micrococcus. I. The isolation, morphology, cultural characteristics and resistance to gamma radiation. Food Technol 10, 575-577.

Asker, D., Awad, T. S., Beppu, T. \& Ueda, K. (2009). Deinococcus aquiradiocola sp. nov., isolated from a radioactive site in Japan. Int $J$ Syst Evol Microbiol 59, 144-149.

Buck, J. D. (1982). Nonstaining $(\mathrm{KOH})$ method for determination of gram reactions of marine bacteria. Appl Environ Microbiol 44, 992-993.

Callegan, R. P., Nobre, M. F., McTernan, P. M., Battista, J. R., NavarroGonzalez, R., McKay, C. P., da Costa, M. S. \& Rainey, F. A. (2008). Description of four novel psychrophilic, ionizing radiation-sensitive Deinococcus species from alpine environments. Int $J$ Syst Evol Microbiol 58, 1252-1258.

Chun, J., Lee, J.-H., Jung, Y., Kim, M., Kim, S., Kim, B. K. \& Lim, Y.-W. (2007). EzTaxon: a web-based tool for the identification of prokaryotes based on $16 \mathrm{~S}$ ribosomal RNA gene sequences. Int J Syst Evol Microbiol 57, 2259-2261.

Counsell, T. J. \& Murray, R. G. E. (1986). Polar lipid profiles of the genus Deinococcus. Int J Syst Bacteriol 36, 202-206.

Daly, M. J., Gaidamakova, E. K., Matrosova, V. Y., Vasilenko, A., Zhai, M., Venkateswaran, A., Hess, M., Omelchenko, M. V., Kostandarithes, H. M. \& other authors (2004). Accumulation of $\mathrm{Mn}(\mathrm{II})$ in Deinococcus radiodurans facilitates gamma-radiation resistance. Science 306, 1025-1028.

Davis, N. S., Silverman, G. J. \& Masurovsky, E. B. (1963). Radiationresistant, pigmented coccus isolated from haddock tissue. J Bacteriol 86, 294-298.

Embley, T. M., O’Donnell, A. G., Watt, R. \& Rostron, J. (1987). Lipid and cell wall amino acid composition in the classification of members of the genus Deinococcus. Syst Appl Microbiol 10, 20-27. 
Ferreira, A. C., Nobre, F. M., Rainey, F. A., Silva, M. T., Wait, R., Burghardt, J., Chung, A. P. \& da Costa, M. S. (1997). Deinococcus geothermalis sp. nov. and Deinococcus murrayi sp. nov., two extremely radiation-resistant and slightly thermophilic species from hot springs. Int J Syst Bacteriol 47, 939-947.

Hirsch, P., Gallikowski, C. A., Siebert, J., Peissl, K., Kroppenstedt, R., Schumann, P., Stackebrandt, E. \& Anderson, R. (2004). Deinococcus frigens sp. nov., Deinococcus saxicola sp. nov., and Deinococcus marmoris sp. nov., low temperature and drought-tolerating, UVresistant bacteria from continental Antarctica. Syst Appl Microbiol 27, 636-645.

Im, W.-T., Jung, H.-M., Ten, L. N., Kim, M. K., Bora, M., Goodfellow, M., Lim, S., Jung, J. \& Lee, S.-T. (2008). Deinococcus aquaticus sp. nov. isolated from freshwater and Deinococcus caeni sp. nov., isolated from activated sludge in South Korea. Int J Syst Evol Microbiol 58, 23482353.

Ito, H., Watanabe, H., Takehisa, N. \& lizuka, H. (1983). Isolation and identification of radiation-resistant cocci belonging to the genus Deinococcus from sewage sludges and animal feeds. Agric Biol Chem 47, 1239-1247.

Kämpfer, P., Lodders, N., Huber, B., Falsen, E. \& Busse, H.-J. (2008). Deinococcus aquatilis sp. nov., isolated from water. Int J Syst Evol Microbiol 58, 2803-2806.

Kumar, S., Tamura, K. \& Nei, M. (2004). MEGA3: integrated software for molecular evolutionary genetics analysis and sequence alignment. Brief Bioinform 5, 150-163.

Lai, W. A., Kämpfer, P., Arun, A. B., Shen, F. T., Huber, B., Rekha, P. D. \& Young, C. C. (2006). Deinococcus ficus sp. nov., isolated from the rhizosphere of Ficus religiosa L. Int J Syst Evol Microbiol 56, 787-791.

Lewis, N. F. (1973). Radio-resistant Micrococcus radiophilus sp. nov. isolated from irradiated Bombay duck (Harpodon nehereus). Curr Sci 42, 504.

Lin, Y.-C., Uemori, K., de Briel, D. A., Arunpairojana, V. \& Yokota, A. (2004). Zimmermannella helvola gen. nov., sp. nov., Zimmermannella alba sp. nov., Zimmermannella bifida sp. nov., Zimmermannella faecalis sp. nov. and Leucobacter albus sp. nov., novel members of the family Microbacteriaceae. Int J Syst Evol Microbiol 54, 1669-1676.

Masters, C. I., Murray, R. G. E., Moseley, B. E. B. \& Minton, K. W. (1991). DNA polymorphisms in new isolates of 'Deinococcus radiopugnans'. J Gen Microbiol 137, 1459-1469.

Mattimore, V. \& Battista, J. R. (1996). Radioresistance of Deinococcus radiodurans: functions necessary to survive ionizing radiation are also necessary to survive prolonged desiccation. J Bacteriol 178, 633637.

Mesbah, M., Premachandran, U. \& Whitman, W. B. (1989). Precise measurement of the $\mathrm{G}+\mathrm{C}$ content of deoxyribonucleic acid by highperformance liquid chromatography. Int J Syst Bacteriol 39, 159-167.

Minton, K. W. (1994). DNA repair in the extremely radioresistant bacterium Deinococcus radiodurans. Mol Microbiol 13, 9-15.

Oyaizu, H., Stackebrandt, E., Schleifer, K. H., Ludwig, W., Pohla, H., Ito, H., Hirata, A., Oyaizu, Y. \& Komagata, K. (1987). A radiationresistant rod-shaped bacterium, Deinobacter grandis gen. nov., sp. nov., with peptidoglycan containing ornithine. Int J Syst Bacteriol 37, 62-67.

Rainey, F. A., Ray, K., Ferreira, M., Gatz, B. Z., Nobre, M. F., Bagaley, D., Rash, B. A., Park, M. J., Earl, A. M. \& other authors (2005). Extensive diversity of ionizing-radiation-resistant bacteria recovered from Sonoran Desert soil and description of nine new species of the genus Deinococcus obtained from a single soil sample. Appl Environ Microbiol 71, 5225-5235.

Schleifer, K. H. \& Kandler, O. (1972). Peptidoglycan types of bacterial cell walls and their taxonomic implications. Bacteriol Rev 36, 407-477.

Smibert, R. M. \& Krieg, N. R. (1994). Phenotypic characterization. In Methods for General and Molecular Bacteriology, pp. 607-654. Edited by P. Gerhardt, R. G. E. Murray, W. A. Wood \& N. R. Krieg. Washington, DC: American Society for Microbiology.

Suresh, K., Reddy, G. S. N., Sengupta, S. \& Shivaji, S. (2004). Deinococcus indicus sp. nov., an arsenic-resistant bacterium from an aquifer in West Bengal, India. Int J Syst Evol Microbiol 54, 457-461.

Thompson, B. G., Anderson, R. \& Murray, R. G. (1980). Unusual polar lipids of Micrococcus radiodurans strain Sark. Can J Microbiol 26, 1408-1411.

Tindall, B. J. (1990). Lipid composition of Halobacterium lacusprofundi. FEMS Microbiol Lett 66, 199-202.

Weeks, O. B. (1955). Flavobacterium aquatile (Frankland and Frankland) Bergey et al., type species of the genus Flavobacterium. $J$ Bacteriol 69, 649-658.

Weon, H. Y., Kim, B. Y., Schumann, P., Son, J. A., Jang, J., Go, S. J. \& Kwon, S. W. (2007). Deinococcus cellulosilyticus sp. nov., isolated from air. Int J Syst Evol Microbiol 57, 1685-1688.

Xie, C. H. \& Yokota, A. (2003). Phylogenetic analysis of Lampropedia hyalina based on the 16S rRNA gene sequence. J Gen Appl Microbiol 49, 345-349. 